\title{
CELLULAR STRATEGIES TO PROMOTE VASCULARISATION IN TISSUE ENGINEERING APPLICATIONS
}

\author{
R. Costa-Almeida ${ }^{1,2}$, P. L. Granja ${ }^{2,3,4}$, R. Soares ${ }^{1, *}$ and S. G. Guerreiro ${ }^{1,5}$ \\ ${ }^{1}$ Faculdade de Medicina, Universidade do Porto, Departamento de Bioquímica (U38-FCT), Porto, Portugal. \\ ${ }^{2}$ Faculdade de Engenharia, Universidade do Porto, Porto, Portugal. \\ ${ }^{3}$ INEB - Instituto de Engenharia Biomédica, Universidade do Porto, Porto, Portugal. \\ ${ }^{4}$ ICBAS - Instituto de Ciências Biomédicas Abel Salazar, Universidade do Porto, Porto, Portugal. \\ ${ }^{5}$ Centro de Neurociências e Biologia Celular, Universidade de Coimbra, Coimbra, Portugal
}

\begin{abstract}
Vascularisation is considered to be one of the greatest challenges in tissue engineering. Different strategies exist but cell-based approaches have emerged as a promising therapy to achieve successful vascularisation. The use of endothelial cells to engineer vascularised tissues has been extensively investigated. This field of research has evolved with the discovery of endothelial progenitor cells, a subpopulation with a high regenerative potential. However, the survival of endothelial cell populations alone seems to be impaired. To overcome this problem, co-culture systems, involving supporting cells, like mural cells, fibroblasts, or more tissue-specific cells have been developed. Endothelial cells benefit from the extracellular matrix components and growth factors produced by the supporting cells, which results in neovessel stabilisation and maturation. The use of endothelial progenitor cells in co-culture systems appears to be a promising strategy to promote vascularisation in approaches of increasing complexity. Herein, the authors provide an overview of the cellular strategies that can be used for increasing vascularisation in tissue engineering and regeneration.
\end{abstract}

Keywords: Angiogenesis, cellular therapies, co-culture models, endothelial progenitor cells, regeneration.

*Address for correspondence:

Raquel Soares

Department of Biochemistry

Faculty of Medicine, University of Porto

Alameda Prof. Hernani Monteiro

4200-319 Porto, Portugal

Telephone/FAX Number: 351225513624

E-mail: raqsoa@med.up.pt

\section{The Relevance of Vascularisation in Tissue Engineering}

The regeneration of a lost or damaged tissue function in the adult generally involves a recapitulation of developmental processes, which consequently implies the replication of biological concepts and instructions expressed during the embryonic development (Lee et al., 2011). This is the main reason why regeneration of large defects in a human adult tissue does not occur naturally.

Tissues are composed of several cell types, resulting in a highly organised complex structure, integrated into the body, namely through the vascular and the nervous systems. Tissue engineering has been evolving as an interdisciplinary science, which intends to restore, maintain or improve tissue function (Langer and Vacanti, 1993). In general terms, tissue engineering aims for the creation of adequate tissue or even organ equivalents, although, up to now, only tissue-engineered products for skin and cartilage regeneration have been successfully used in the clinics (Phelps and García, 2010). One explanation for this fact is based on the recognition that the demands of skin and cartilage in terms of blood supply are relatively reduced (and virtually non-existent in cartilage), owing to the fact that these tissues are supplied through diffusion from distant blood vessels. However, the maximum diffusion distance of nutrients and oxygen out of blood vessels is of about $200 \mu \mathrm{m}$ (Carmeliet and Jain, 2000) and, due to mass transfer limitations, organs with a more complex three-dimensional structure actually need an integrated vascular network to support cell survival. Overall, the inability to engineer blood vessels in vitro for subsequent transplantation has been referred to as the main reason associated with the limited clinical success of tissue engineering strategies (Lovett et al., 2009; Phelps and García, 2010; Novosel et al., 2011).

When a tissue engineered construct, including transplanted cells, faces an insufficient blood stream, associated problems arise that result in functional limitations of the bioengineered tissue or even lead to the failure of the implanted construct. Hence, several strategies have been investigated with the aim of promoting vascularisation in tissue engineering applications, namely growth factor delivery, cell transplantation, and the use of materials for immobilisation strategies (scaffold-based approaches), which have been extensively reviewed (Rouwkema et al., 2008; Lovett et al., 2009; Phelps and García, 2010; Novosel et al., 2011). In fact, there have been different efforts to develop new therapies so that a faster and successful vascularisation is achieved. This 
Fig. 1. Summary of strategies used to promote vascularisation in tissue engineering applications. Growth factor delivery and cell transplantation are traditional strategies that present several associated problems and have been improved through their combination and the use of scaffold materials.

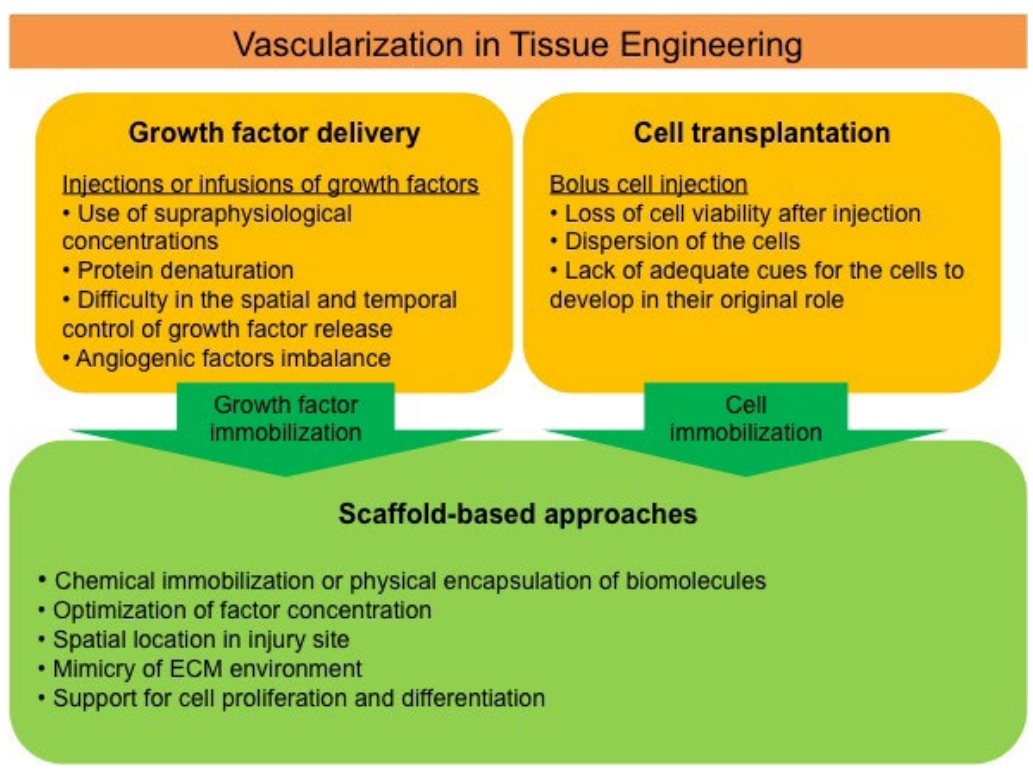

review will discuss the usefulness of cellular therapies as a strategy, focusing on the relevance of endothelial progenitor cells as a promising source of endothelial cells (ECs), as well as on the importance of co-culture systems and the need to increase their complexity to promote vascularisation in tissue engineering (Fig. 1).

\section{The Vascular System}

The vascular network is responsible not only for the transport of gases, nutrients and metabolites, but also for the circulation of signalling molecules, hormones, and antibodies between tissues and organs. The complex structure of the vascular network is achieved by the maturation of the immature blood vessels previously formed by angiogenesis or vasculogenesis (Jain, 2003). Vasculogenesis refers to the in situ formation of vessels orchestrated directly by endothelial precursor cells or angioblasts, which is of major importance during embryonic development, but also plays a role in adulthood, both under physiological as well as under pathological conditions (Asahara et al., 1999; Conway et al., 2001). On the other hand, angiogenesis is defined as the process of new blood vessel formation through the sprouting of preexisting vasculature. For this, specific proteases initiate the degradation of the extracellular matrix (ECM), enabling endothelial cells (ECs) to change polarisation, proliferate and invade the ECM towards the avascular tissue (Costa et al., 2007; Soares, 2009). As ECM is degraded, ECs migrate to distant sites, anastomose and acquire lumens, forming the neovessel, which is then stabilised by the assembly of a basement membrane and adhesion of pericytes. Other stromal cells, such as fibroblasts, also contribute to the formation of the neovessel by releasing growth factors and ECM components. In contrast, vasculogenic processes require circulating endothelial progenitor cells (EPCs) to be stimulated to differentiate into functional ECs that adhere to a vascular bud, assembling into the newly formed vessel (Costa et al., 2007; Soares, 2009). Similar to angiogenesis, this process ends by the attachment of mural cells that stabilise the vessel.

Therefore, angiogenesis plays a crucial role throughout postnatal life, and is related to wound healing and the menstrual cycle (Soares, 2009), inflammatory processes, and also some pathological conditions, such as rheumatoid arthritis, diabetic retinopathy, macular degeneration and tumour growth (Costa et al., 2007; George et al., 2011). Furthermore, angiogenesis accompanies growth repair, tissue remodelling and regeneration (Carmeliet and Jain, 2000; Jain, 2003; Carmeliet, 2005; Carmeliet and Jain, 2011). The recruitment of new blood vessels through the activation of these two main processes of vascularisation is still considered to be a great challenge in regenerative therapies.

Different blood vessels exist, including arteries, veins and small calibre vessels (arterioles, venules and capillaries) that express characteristic molecular markers. Endothelial precursors that form arteries express ephrin B2 (Efnb2), whereas its receptor, the B4 ephrin receptor (Ephb4), is preferentially expressed in veins (Lin et al., 2007). However, all blood vessels are formed by one thin inner layer of ECs, the endothelium, which is then covered by supporting/mural cells. This vascular endothelium provides a selective barrier, separating the blood stream from the underlying tissues, with vascular wall cells being thus embedded in an extracellular matrix (Fig. 2).

\section{Vascular Wall Cells}

\section{Endothelial cells and endothelial progenitor cell populations}

Endothelial cells, forming the endothelium, play a pivotal role in vascularisation. They characteristically express von Willebrand factor (vWF), platelet endothelial cell adhesion molecule-1 (PECAM-1 or CD31), and vascular endothelial (VE)-cadherin (Muller et al., 2002; Fuchs et al., 2006a; Fuchs et al., 2006b; Medina et al., 2010a). To maintain the integrity of the endothelium, ECs communicate with 


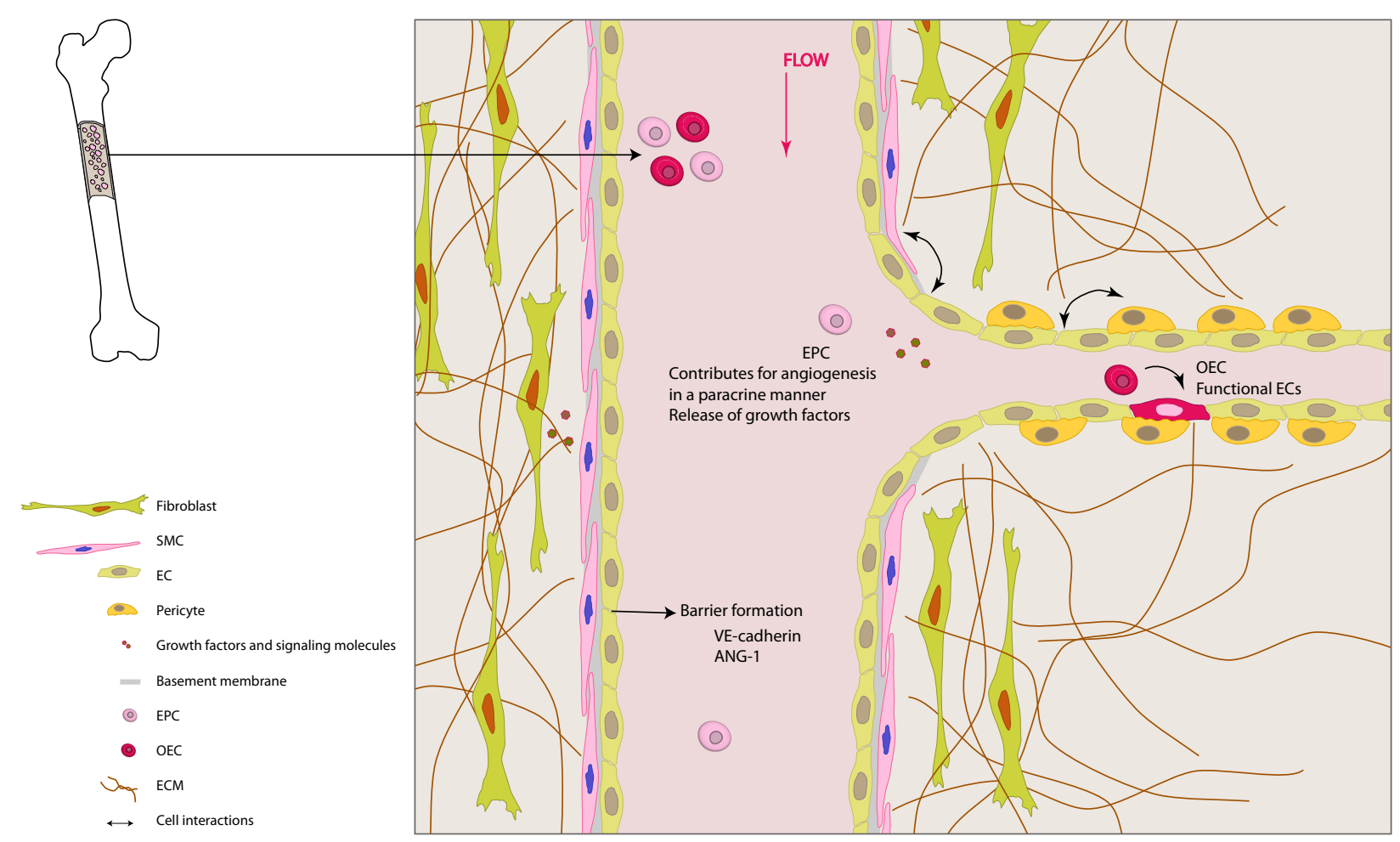

Fig. 2. Schematic representation of the biological processes involved in vascularisation, including cell-cell/ cell-matrix interactions. The vascular endothelium is formed by one layer of endothelial cells (EC). Their expression of adhesion molecules, like VE-cadherin and Ang-1, allows for intercellular interactions, which are important for vessel stabilisation. Vascular maintenance is achieved through specific signalling (release of growth factors and signalling molecules) and direct physical contact between endothelial cells and mural cells, such as smooth muscle cells (SMC) and pericytes, or fibroblasts. The extracellular matrix (ECM) will act as a bridge between blood vessels and the surrounding tissue. Moreover, different populations of endothelial progenitor cells exist in circulation - early endothelial progenitor cells (EPC) and outgrowth endothelial cells (OEC). These cells have distinct roles in vascularisation: EPCs contribute to vascularisation/angiogenesis in a paracrine manner through the release of growth factors, while OECs are able to contribute for the repair and formation of blood vessels by differentiating into mature ECs.

each other through adhesion molecules, like VE-cadherin (Vestweber, 2008), present in adherence junctions, and tight junctions, among other structures (Dejana et al., 1995; Liebner et al., 2006), as well as with neighbouring cells. For instance, connexin (Cx)43 and Cx45 are involved in heterotypic communication with mesenchymal stem cells (MSCs), influencing their differentiation (Villars et al., 2002; Hirschi et al., 2003; Fang et al., 2013).

However, molecular differences exist between endothelial cell populations due to the heterogeneity along this cell lineage (Craig et al., 1998), resulting in high variability when their functional behaviour is assessed through angiogenesis assays, as discussed elsewhere (Staton et al., 2009). Some authors consider that mature ECs present a limited regenerative potential (Sieveking et $a l ., 2008)$. The discovery of putative endothelial progenitor cells (EPCs) in 1997 (Asahara et al., 1997) contributed to enlarge the knowledge about endothelial cell populations and to change the, until then, prevailing dogma. This stated that throughout postnatal life, new blood vessels could only be generated by fully differentiated ECs. In fact, blood vessels are believed to originate from endothelial precursors (Carmeliet, 2005). Another important characteristic of ECs that contributes to tissue engineering is their plasticity and, consequently, their ability to dedifferentiate into stem cells when stimulated to undergo endothelial-mesenchymal transition, which makes them a potential cell source for use in regenerative strategies, as reviewed elsewhere (Susienka and Medici, 2013).

Although embryonic and adult stem cells exhibit a higher proliferative capacity (Rafii and Lyden, 2003), the use of EPCs emerged as an alternative (Ankeny et al., 2012). EPCs exist in circulation and have been described as being capable of incorporating into vessels after mobilisation from bone marrow, in order to participate in neovascularisation at sites of ischaemia (Asahara et al., 1997). Using these cells overcomes some ethical considerations, along with a deficient knowledge considering the control of stem cell differentiation (MeleroMartin et al., 2007). Two different types of EPCs are believed to exist, early EPCs and late EPCs, here called outgrowth endothelial cells (OECs) (Lin et al., 2000; Sieveking et al., 2008; Medina et al., 2010a; OshimaSudo et al., 2011); these cells are commonly isolated from peripheral or umbilical cord blood (Asahara et al., 1997; Ingram et al., 2004; Fuchs et al., 2006a; Fuchs et 
al., 2006b; Au et al., 2008a). Other sources of endothelial progenitors include bone marrow (BM) (Shi et al., 1998; Asahara et al., 1999; Nolan et al., 2007; Chen et al., 2012), amniotic fluid (Zhang et al., 2009) and adipose tissue (Lin et al., 2008; Szöke et al., 2012). At the same time, new hypotheses about the origin of OECs have emerged in the literature. Tura et al. reported that OECs cannot be isolated from bone marrow nor from cells mobilised from this site (Tura et al., 2013). Accordingly, Zhang et al. demonstrated that cells isolated from bone marrow with high proliferation during long-term culture were consistently mesenchymal stromal cells and did not differentiate toward the endothelial lineage when cultured under endothelium- promoting conditions (Zhang et al., 2007). This finding defies the concept of BM-derived circulating precursors of endothelial cells, giving rise to further speculation about the possible existence of a vascular source outside the bone marrow. Nevertheless, further studies are needed to confirm this hypothesis.

Despite their origin, these progenitor cells seem to be mobilised into the circulation, contributing to the neovascularisation process (Asahara et al., 1997; Asahara et al., 1999; Rafii and Lyden, 2003). However, there is still great controversy associated with the term "endothelial progenitor cell" or the cell type that might be preferred for a therapeutic application (Fuchs et al., 2010). Indeed, key issues remain unanswered, like the lack of uniform cellular definitions, and the inadequate functional characterisation (Sieveking et al., 2008; Medina et al., 2010b; OshimaSudo et al., 2011). Early EPCs have been described as BM-derived cells sharing surface markers expressed by haematopoietic stem cell populations, such as CD14, CD45 and CD133 (Asahara et al., 1997; Masuda and Asahara, 2003; Medina et al., 2010a; Doulatov et al., 2012), differentiating into phagocytic macrophages and possessing myeloid progenitor cell activity (Yoder et al., 2007; Shi et al., 2014). These cells appear after 4 to 7 days in culture and are thought to provide angiogenic factors, acting in a paracrine manner, whereas OECs appear much later, after 14 to 21 days, exhibiting typical endothelial characteristics and being reported to incorporate into resident vasculature (Mukai et al., 2008; Sieveking et al., 2008; Oshima-Sudo et al., 2011). Moreover, early EPCs have been shown to preferentially express genes involved in immune responses and inflammation, while OECs express genes involved in development and angiogenesis, including the angiopoietin receptor Tie2, endothelial nitric oxide synthase (eNOS), ephrins and transforming growth factor- $\beta$ (TGF- $\beta$ ) (Cheng et al., 2013; Medina et al., 2010a). A more recent study also showed that umbilical cord blood (UCB)-derived OECs secrete a broad spectrum of pro-inflammatory and angiogenic cytokines, including angiogenin, angiopoietin (Ang)-2 and platelet-derived growth factor (PDGF)-BB (Liu et al., 2012), one of the four homodimeric glycoproteins from PDGF family.

In addition, mature ECs are also capable of producing ECM components (Hurley et al., 2010). Similarly, OECs have been reported to deposit collagen IV, laminin and fibronectin with an increasing organisation over time (Kusuma et al., 2012), which is essential for EC assembly.

\section{Mural cells}

Mural cells are recruited to allow vessel maturation and stability (Jain, 2003). ECs first associate to form tubules and afterwards different signals are involved in the recruitment and coverage of ECs by mural cells, including platelet-derived growth factor (PDGF)-B, Ang-1, TGF- $\beta$ and NOTCH signalling (Carmeliet and Jain, 2011).

Different mural cells exist depending on their morphology, location and the expression of specific markers, being divided into pericytes and smooth muscle cells (SMCs) (Gaengel et al., 2009). Vascular SMCs are present in larger blood vessels, such as arteries and veins, forming multiple concentric layers, being embedded within the vascular basement membrane and, consequently, separated from the endothelium. On the other hand, pericytes cover capillaries and other microvessels, being often organised in a discontinuous cell layer around the endothelial cell tube (Gaengel et al., 2009). Newly formed vasculature would regress without the support of these periendothelial cells (Conway et al., 2001), which contribute to stabilise blood vessels through direct physical contact (Bergers and Song, 2005), ECM deposition (Njauw et al., 2008) and growth factors release, as vascular endothelial growth factor (VEGF) and Ang-1 (Bergers and Song, 2005; Njauw et al., 2008; Carmeliet and Jain, 2011).

Mural cells not only stabilise blood vessels by inhibiting EC proliferation and migration, but are also involved in the modulation of blood flow and vessel permeability.

Different tissues exhibit varying mural cell phenotypes and different degrees by which they cover the endothelium (Gaengel et al., 2009); thus, one cell type might be better suited - depending on the application of the vascularised engineered tissue construct.

\section{Fibroblasts}

Fibroblasts are mesenchymal cells, and can be quite different in terms of cell dynamics, depending on their tissue of origin (Chang et al., 2002). They are the main source of ECM components (Chang et al., 2002; Kalluri and Zeisberg, 2006), including collagen I, fibronectin and proteoglycans (Mansbridge et al., 1999). Human fibroblasts are abundant in the dermis and can be easily obtained from minimally invasive skin biopsies, using standard laboratory protocols (Wong et al., 2007; Junker et al., 2013). Consequently, fibroblasts were the first cells from which induced pluripotent stem cells (iPSCs) were obtained, first from mice (Takahashi and Yamanaka, 2006) and then from human origin (Takahashi et al., 2007). Sir John B. Gurdon and Shinya Yamanaka were awarded the 2012 Nobel Prize in Physiology or Medicine for their research in the area of reprogramming mature cells to become pluripotent (Yamanaka, 2013). Since the discovery of iPSCs, human fibroblasts have been reprogrammed to become endothelial cells in response to defined media and culture conditions, being able to form capillary-like structures in vivo in a Matrigel plug mice model (Margariti et al., 2012). Therefore, human dermal fibroblasts have been much used for skin tissue engineering applications and have gained an increasing interest as a cell source for other applications, like neovascularisation. For instance, the adventitial layer of large blood vessels 
is mainly composed of fibroblasts and associated ECM components (Njauw et al., 2008). Fibroblasts secrete potent angiogenic factors, like VEGF and fibroblast growth factor (FGF)-2, as well as matrix metalloproteinase (MMP)-2 and MMP-9 (Berthod et al., 2006), which in turn act by releasing pro-angiogenic peptides. Hence, it is possible that fibroblasts act as peri-endothelial progenitors in vivo (Njauw et al., 2008), supporting EC survival and migration, as well as modulating the expansion of capillary-like networks, particularly in vitro (Kunz-Schughart et al., 2006). Moreover, since fibroblasts generate a scaffold for other cells through matrix deposition, they may alter the mechanical extracellular microenvironment, thus regulating the vascularisation processes (Hurley et al., 2010).

\section{The extracellular matrix}

The ECM acts as a bridge between vascular wall cells and the respective surrounding tissues. Providing a 3D support for EC proliferation and survival, the ECM has a dual role - it acts as an adequate substrate for the organisation of ECs into microvessels, simultaneously retaining and concentrating growth factors in the cellular microenvironment (Berthod et al., 2006). ECM is therefore considered a reservoir of proteins that are involved in several physiological events, including wound healing and angiogenesis. The presence of proteases or protease inhibitors leads to changes in the bioavailability of matrixsequestered factors (Sottile, 2004).

Capillary morphogenesis is regulated through the immobilisation of angiogenic cytokines, growth factors and other molecular cues involved in angiogenic activation (e.g., collagen I) (Davis and Senger, 2005), as well as by angiogenesis inhibitors (Hynes, 2007). MMPs exist, which release pro-angiogenic (Demidova-Rice et al., 2011) and anti-angiogenic peptides (Brauer et al., 2011), through ECM cleavage. In particular, the endothelium is separated from the connective tissue by the basement membrane, a specialised layer of ECM where collagen IV and laminin organise into networks, being both essential for basement membrane stability (LeBleu et al., 2007). For instance, collagen IV has been described as having the capacity to modulate the angiogenic response in a rat aorta model, resulting in the elongation of the neovessels (Bonanno et $a l ., 2000)$. On the other hand, cleavage of collagen IV may result in the release of tumstatin and other angiogenesis inhibitors (Hynes, 2007).

Given that ECM proteins also possess binding sites for cells to adhere to through their surface receptors, ECM acts as a key controller of cell behaviour, activating several intracellular signalling pathways and, in turn, cells degrade and remodel the ECM (Davis and Senger, 2005; LeBleu et al., 2007; Daley et al., 2008). The ECM corresponds, thus, to a natural scaffold for tissue development and repair, supporting tissue reconstruction (Badylak, 2002). Hence, understanding cell-matrix interactions is of major importance to mimic the natural ECM when developing functionalised artificial matrices (Munarin et al., 2011).

\section{Cellular therapies to promote vascularisation}

Despite the great advances in the field of tissue regeneration, the vascularisation of an implanted scaffold is still a critical aspect. Two approaches have emerged aiming at solving this problem (Fig. 3). One is focused on culturing cells into the scaffold and implanting the system without any cell organisation, while the other consists of pre-vascularising the system prior to implantation. However, it is not known which strategy would lead to a better functional anastomosis between vessels formed in the scaffold and the host vasculature.

\section{Transplantation of endothelial populations}

Cell transplantation, particularly of ECs, has been the focus of several strategies aiming at promoting vascularisation. Endothelial cells, particularly progenitor cells, have been widely investigated to treat cardiovascular diseases. Provided that progenitor cell populations (both EPCs and OECs) can be easily isolated from blood, their use in an autologous way constitutes a major advantage for clinical applications. Clinical trials concerning the transplantation of both UCB-derived progenitor cells and BM-derived mononuclear cells have proved the potential of these cells for the treatment of cardiovascular diseases, since significant beneficial effects on left ventricle remodelling processes were observed in patients with acute myocardial infarction (TOPCARE-AMI trial) after cell transplantation (Assmus et al., 2002; Britten et al., 2003; Schächinger et al., 2004).

In addition, the use of EPCs in animal models has been proven efficient concerning revascularisation of injured tissues. In general, the delivery of EPCs, particularly through hydrogels, has been reported to promote systemic and renal protective effects in mice during the treatment of acute kidney injury conditions, such as induced nephropathy, endotoxaemia and sepsis, leading to an improvement of microvascular competence, as reviewed elsewhere (Ratlif and Goligorsky, 2013). Endothelial cells have also been used to treat other ischaemic lesions. Exogenous administration of human peripheral blood (PB)derived EPCs in a murine model of hind limb ischaemia resulted in an improvement of vascularisation, together with blood flow recovery and a reduction in limb necrosis and auto-amputation (Kalka et al., 2000). Silva and colleagues (2008) implanted human UCB-derived EPCs and OECs together using an artificial ECM as a scaffold (modified alginate) in a peripheral artery disease mouse model and showed that this co-transplantation approach provided a great benefit for the neovascularisation of ischaemic muscle tissue, compared to the delivery of each cell population separately (Silva et al., 2008). This study demonstrated that the co-transplantation of cell populations with complementary functions might result in a broad benefit in vascularisation strategies and revealed that the utility of EPCs highly depends on the delivery mode, as well as on the control over cell fate after transplantation.

Vascularisation of 3D tissue engineered structures strongly depends on cell viability. When ECs are cultured alone, their survival seems to be impaired. Studies reporting 


\section{A CO-CULTURE BASED TISSUE ENGINEERING APPROACH}

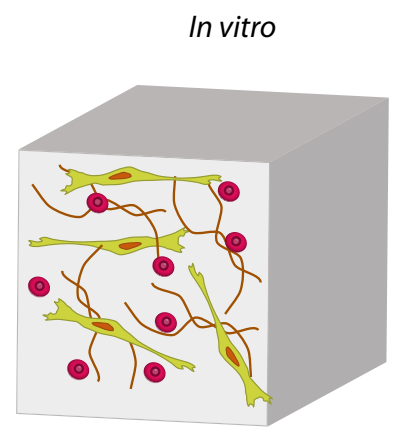

Seeding of ECs and support cells into a 3D scaffold
EC-MURAL CELL INTERACTIONS

Mural cells produce ECM to support EC survival and to guide migration, proliferation and organization into tubular-like structures

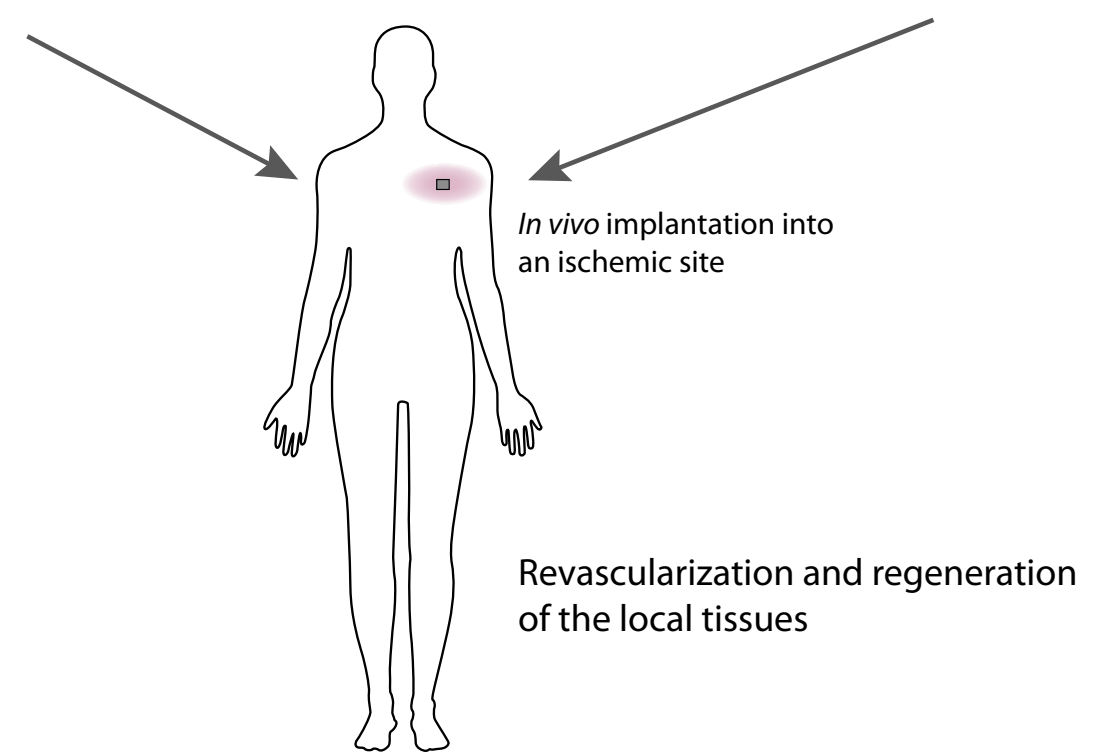

In vitro

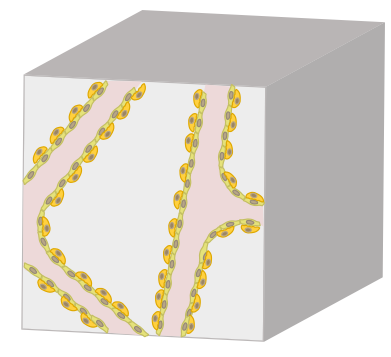

Development of an in vitro prevascularized 3D construct

Fig. 3. A co-culture-based tissue engineering approach for the improvement of revascularisation and regeneration of ischaemic tissues. One strategy consists of seeding endothelial cells (EC) and mural cells in a 3D scaffold followed by in vivo implantation. Another strategy involves the development of a prevascularised 3D scaffold before in vivo implantation.

the presence of cells that express $\alpha$-smooth muscle actin $(\alpha-$ SMA), a phenotypic marker of myofibroblasts and pericytes, around blood vessels, strongly suggest that formation of a stable vascular network by ECs is highly dependent on their co-implantation with supporting perivascular cells (Melero-Martin et al., 2007; Njauw et al., 2008; Finkenzeller et al., 2009; Chen et al., 2010; Dohle et al., 2011; Berthod et al., 2012).

\section{Co-culture systems}

The importance of a co-culture system relies on the intricate communication pathways that are established between different cell types, both through diffusible signalling molecules and by cell-cell contacts, with angiogenesis being controlled by the interaction between ECs and other cell types (Fuchs et al., 2007). Hence, this section will focus on the use of ECs in co-culture systems to promote vascularisation in tissue engineering. Table 1 summarises the state-of-the-art literature regarding $2 \mathrm{D}$ and $3 \mathrm{D}$ coculture systems for tissue engineering purposes.

\section{Co-cultures of ECS with pericytes}

Pericytes have been recently described as $\mathrm{CD} 146^{+}$and CD34- cells; however, these markers are not reliable in vitro and functional assays are needed (Blocki et al., 2013). Nevertheless, pericytes were considered as a multipotent population, sharing commonly accepted MSC markers and features, as discussed elsewhere (Chen et al., 2009a). Recent advances have suggested that pericytes might include multilineage progenitors (Crisan et al., 2008) and that the walls of blood vessels can possibly be a source of these stem/progenitor cells (Corselli et al., 2012).

Pericytes have been investigated in co-culture systems with endothelial cells to mimic the blood brain barrier (Hayashi et al., 2004; Zozulya et al., 2008), or the gliovascular complex from the neurovascular unit (Itoh et al., 2011), as well as the retinal microvascular environment to study diabetic retinopathy (Tarallo et al., 2012). Although pericytes are described as being capable of protecting the blood brain barrier from disruption, for instance, following short periods of hypoxia (Hayashi et 
Table 1. Examples of co-cultures of endothelial cells and support cells.

\begin{tabular}{|c|c|c|c|c|}
\hline $\begin{array}{l}\text { 2D or } \\
\text { 3D } \\
\text { culture }\end{array}$ & $\begin{array}{l}\text { In vitro } \\
\text { or } \\
\text { in vivo }\end{array}$ & Cell types used & Main results & References \\
\hline \multirow[t]{3}{*}{$2 \mathrm{D}$} & In vitro & $\begin{array}{l}\text { - Pericytes } \\
\text { - HUVECs }\end{array}$ & $\begin{array}{l}\text { In co-cultures, ECs stimulated the activation of pericytes, } \\
\text { which produced VEGF, leading to EC organisation into } \\
\text { capillary-like structures after } 24 \mathrm{~h} \text {. }\end{array}$ & (Kale et al., 2005) \\
\hline & In vitro & $\begin{array}{l}\bullet \text { MSCs } \\
\bullet \text { ECs (HDMECs, OECs) }\end{array}$ & 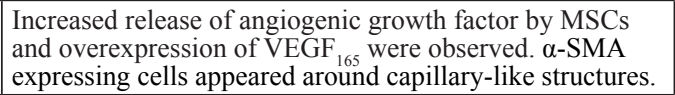 & $\begin{array}{l}\text { (Kolbe et al., 2011; } \\
\text { Laranjeira et al., 2012) }\end{array}$ \\
\hline & In vitro & $\begin{array}{l}\text { - Osteoprogenitor cells } \\
\text { - ECs (HUVECs, HDMECs, } \\
\text { OECs) }\end{array}$ & $\begin{array}{l}\text { ECs expressed BMP- } 2 \text { and BMP- } 4 \text { and increased MSCs } \\
\text { differentiation, together with a higher angiogenic activity. } \\
\text { Increased expression of osteogenic differentiation markers } \\
\text { have been detected. }\end{array}$ & $\begin{array}{l}\text { (Bidarra et al., 2011; } \\
\text { Grellier et al., 2009a; } \\
\text { Guillotin et al., 2008; } \\
\text { Kaigler et al., 2005; Smadja } \\
\text { et al., 2008) }\end{array}$ \\
\hline \multirow[t]{13}{*}{ 3D } & In vivo & $\begin{array}{l}- \text { Pericytes (derived from } \\
\text { 10T1/2) } \\
\text { - EPCs }\end{array}$ & $\begin{array}{l}\text { In co-implantation approaches, EPCs aligned into } \\
\text { functional blood vessels. }\end{array}$ & (Au et al., 2008a) \\
\hline & $\begin{array}{l}\text { In vitro/ } \\
\text { In vivo }\end{array}$ & $\begin{array}{l}- \text { Pericytes } \\
\bullet \text { HUVECs }\end{array}$ & $\begin{array}{l}\text { Pericytes supported the assembly of ECs into capillary- } \\
\text { like structures in 3D Matrigel assay/ Improved } \\
\text { angiogenesis in a myocardial infarction mouse model. }\end{array}$ & (Chen et al., 2013) \\
\hline & In vivo & $\begin{array}{l}- \text { HUASMCs } \\
\bullet \text { HUVECs }\end{array}$ & $\begin{array}{l}\text { The implantation of a decellularised small intestinal } \\
\text { mucosa scaffold led to a rapid vascularisation of the graft. }\end{array}$ & (Wang et al., 2012) \\
\hline & In vivo & • SMCs & $\begin{array}{l}\text { Co-implantation resulted in a higher microvascular } \\
\text { density than that of OECs alone. Functional anastomoses } \\
\text { with the host vasculature have been observed. }\end{array}$ & $\begin{array}{l}\text { (Foubert et al., 2008; } \\
\text { Melero-Martin } \text { et al., 2007) }\end{array}$ \\
\hline & In vitro & $\begin{array}{l}\text { - Fibroblasts } \\
\text { - HUVECs }\end{array}$ & $\begin{array}{l}\text { Fibroblast-derived matrix was essential for lumen } \\
\text { formation by ECs. } \alpha \text {-SMA expressing cells appeared } \\
\text { around capillary-like structures. Fibroblasts supported the } \\
\text { assembly of ECs into capillary-like structures. }\end{array}$ & $\begin{array}{l}\text { (Berthod et al., 2006; } \\
\text { Berthod et al., 2012; } \\
\text { Griffith et al., 2005; } \\
\text { Guerreiro et al., 2013; } \\
\text { Kunz-Schughart et al., } \\
\text { 2006; Newman et al., 2011) }\end{array}$ \\
\hline & In vivo & $\begin{array}{l}\text { - Fibroblasts } \\
\text { - OECs }\end{array}$ & $\begin{array}{l}\text { In a prevascularisation approach, blood perfusion and } \\
\text { anastomosis with the host vasculature occurred faster } \\
\text { (within } 27 \mathrm{~h} \text { ). OECs accelerated wound healing by } \\
\text { incorporating into newly formed blood vessels and } \\
\text { promoting oxygenation. }\end{array}$ & $\begin{array}{l}\text { (Chen et al., 2010; } \\
\text { Hendrickx et al., 2010) }\end{array}$ \\
\hline & In vivo & $\begin{array}{l}\cdot \text { MSCs } \\
\bullet \text { HUVECs }\end{array}$ & $\begin{array}{l}\text { MSCs differentiated into pericytes and stabilised the } \\
\text { newly formed vasculature for more than } 130 \text { days. }\end{array}$ & (Au et al., 2008b) \\
\hline & In vitro & $\begin{array}{l}- \text { MSCs } \\
\bullet \text { ECs (progenitor-derived) }\end{array}$ & $\begin{array}{l}\text { An increased mRNA expression of junctional proteins } \\
\text { (connexin 43) was observed. }\end{array}$ & (Guerrero et al., 2013) \\
\hline & In vitro & $\begin{array}{l}\bullet \mathrm{MSCs} \\
\bullet \mathrm{EPCs}\end{array}$ & $\begin{array}{l}\text { MSCs influenced the differentiation of EPCs towards an } \\
\text { endothelial functional phenotype and the formation of } \\
\text { capillary-like structures was observed after } 7 \text { days. EPCs } \\
\text { influenced the differentiation of MSCs towards a pericyte- } \\
\text { like phenotype. }\end{array}$ & $\begin{array}{l}\text { (Duttenhoefer } \text { et al., 2013; } \\
\text { Loibl et al., 2014) }\end{array}$ \\
\hline & In vivo & $\begin{array}{l}\text { - HBMSCs } \\
\bullet \text { ECs (HDMECs, HUVECs) }\end{array}$ & $\begin{array}{l}\text { ECs functioned to form vasculature and to promote } \\
\text { osteogenic differentiation. Significant mineralisation has } \\
\text { been observed in a bone defect. }\end{array}$ & $\begin{array}{l}\text { (Grellier et al., 2009b; } \\
\text { Kaigler et al., 2005) }\end{array}$ \\
\hline & In vivo & $\begin{array}{l}\text { - Osteoblasts/ } \\
\text { osteoprogenitors } \\
\text { - OECs }\end{array}$ & $\begin{array}{l}\text { Co-implantation resulted in a rapid formation of OEC- } \\
\text { derived vessels, which were shown to be functional } \\
\text { (i.e. anastomosed with the host vasculature and were } \\
\text { functional). }\end{array}$ & $\begin{array}{l}\text { (Fuchs et al., 2009; } \\
\text { Ghanaati et al., 2011) }\end{array}$ \\
\hline & In vitro & $\begin{array}{l}\text { - Hepatocytes } \\
\text { - ECs }\end{array}$ & $\begin{array}{l}\text { ECs supported the maintenance of hepatocyte-specific } \\
\text { functions, while organising into capillary-like structures. }\end{array}$ & $\begin{array}{l}\text { (Salerno et al., 2011; Shang } \\
\text { et al., 2014) }\end{array}$ \\
\hline & In vitro & $\begin{array}{l}\text { - Cardiomyocytes } \\
\text { - HUVECs }\end{array}$ & $\begin{array}{l}\text { ECs organised into capillary-like structures and } \\
\text { contributed for the survival and contractility of cardiac } \\
\text { cells. }\end{array}$ & (Garzoni et al., 2009) \\
\hline
\end{tabular}

al., 2004), studies in the field of vascularisation are still scarce. Some authors developed in vitro models of the gliovascular complex and reported that capillary-like structures are maintained over time, due to the presence of pericytes in co-cultures of endothelial cells and astrocytes (Itoh et al., 2011), but pericytes are not the focus of these research models.

On the other hand, the 10T1/2 cell system, a mouse embryonic cell line, has been used as a precursor of pericytes or SMCs, since their differentiation can be induced by TGF- $\beta$, produced by human umbilical vein endothelial cells (HUVECs) in a co-culture system (Kale et al., 2005). In turn, pericytes were shown to produce VEGF, stimulating ECs to organise into capillary-like structures, with markers of activated pericytes, like aminopeptidase
$\mathrm{N}$, being detected after the first $24 \mathrm{~h}$ of culture (Kale et al., 2005).

The same pericyte precursors were also used by Au and colleagues (2008) to investigate whether the implantation of higher cell densities of UCB-derived EPCs could obviate the need for a co-implantation approach (Au et al., 2008a). Although some of the implanted EPCs aligned into blood vessels, these vessels were only transiently perfused and regressed after 23 days, with 10T1/2 cells functioning as perivascular cells in vivo (Au et al., 2008a).

Recently, human pericytes started to be used - aiming at tissue engineering applications. Human microvascular pericytes, isolated from skeletal muscle biopsies, have been shown to improve cardiac function of ischaemic heart after intra-myocardial injection, being able to promote host 
angiogenesis both in the peri-infarct areas and within the blood-deprived infarct region (Chen et al., 2013). The same study also demonstrated that pericytes support HUVECs in the formation of capillary-like structures in an in vitro 3D Matrigel assay (Chen et al., 2013).

Despite the fact that vascularisation starts with capillaries and progressively increases complexity in terms of cell organisation, co-culture models have been focusing on cells that are mainly present in large vessels, instead of aiming to understand the role of pericytes in supporting vascularisation. Nevertheless, pericytes have been applied in implantation strategies using immunecompetent mouse models and no inflammatory response was detected (He et al., 2010). Although further studies are needed, this immunosuppressive function of pericytes might be favourable for future clinical use of these cells, if they are of heterologous source.

Co-cultures of ECs with smooth muscle cells

SMCs are involved in the stabilisation and maturation of blood vessels. A recent study has shown that implantation of a decellularised porcine small intestinal mucosa scaffold reseeded with HUVECs and human umbilical artery SMCs (HUASMCs) resulted in a rapid vascularisation (4 days) of the graft, together with the maintenance of favourable mechanical properties of the tissue engineered vascular grafts (Wang et al., 2012).

Co-administration of ECs and SMCs has also been investigated in models of ischaemia. For instance, Foubert et al. implanted endothelial and smooth muscle progenitor cells, both isolated from human UCB (OECs and SMPCs, respectively), in combination into an ischaemic leg of nude mice and verified that this combined administration resulted in a higher microvascular density, compared to OECs implanted alone (Foubert et al., 2008). In addition, molecular events that are involved in vascularisation steps also appear to be different in co-culture systems, compared to ECs cultured alone. For instance, PDGF-B was found to be down-regulated over time in co-culture spheroids of HUVECs/HUASMCs, contrasting to HUVECs alone (Korff et al., 2001). This suggests that co-cultures properly mimic the in vivo phenotype (Korff et al., 2001), since the expression of PDGF-B is restricted to immature capillaries. Besides, Foubert et al. have demonstrated that SMCs released Ang-1 and its receptor Tie-2 was subsequently activated in OECs, showing that paracrine release of Ang-1 modulated OEC incorporation into the vascular endothelium (Foubert et al., 2008).

In addition, Melero-Martin and colleagues first demonstrated the in vivo vasculogenic potential of OECs by performing a co-implantation protocol of both human UCB- or PB-derived OECs together with SMCs in Matrigel plugs through subcutaneous injection into immunodeficient mice. This approach resulted in the formation of human EC-lined vessels, which contained murine erythrocytes, with functional anastomoses being observed (MeleroMartin et al., 2007). They have shown that blood vessel formation occurred only for co-implantation experiments (Melero-Martin et al., 2007), reinforcing the importance of cellular crosstalk.

\section{Co-cultures of ECs with fibroblasts}

In the past decade, different works have focused on the potential of fibroblasts to enhance vascularisation. The implantation of neonatal human dermal fibroblasts using Matrigel plugs in mice showed that fibroblasts induced the ingrowth of blood vessels from the host vasculature (Guerreiro et al., 2012), thus suggesting that these cells take part in the recruitment of ECs in vivo. Moreover, a combination of fibroblast-derived proteins, comprising Ang-1, angiogenin, hepatocyte growth factor (HGF), TGF- $\alpha$ and tumour necrosis factor (TNF), has been described to support EC sprouting, while matrix proteins, such as collagen I, secreted protein acidic and rich in cysteine (SPARC) and insulin-like growth factor-binding protein 7 (IGFBP7), among other factors, were necessary for lumen formation by HUVECs co-cultured with normal human lung fibroblasts in 3D fibrin gels, which proved to be related to an increased matrix stiffness (Newman et al., 2011). In particular, when ECM synthesis by fibroblasts is reduced, EC tube formation is decreased (Berthod et al., 2006). However, ECM synthesis seems not sufficient for the organisation of capillary-like structures, which requires a close association between ECs and living fibroblasts (Berthod et al., 2006). It has also been described that pericytes spontaneously originate from fibroblasts, when co-culture systems with ECs are established (Berthod et al., 2012). In addition, a spheroid co-culture model has demonstrated that HUVECs were capable of attaching and migrating along human foreskin fibroblasts-derived ECM in order to form a capillary-like network (Kunz-Schughart et al., 2006). Griffith et al. reported a rapid sprouting of HUVECs seeded on microcarrier beads and co-cultured with human dermal fibroblasts, with capillary-like networks forming in a fibrin-based tissue construct after 2-3 days and continuing to remodel up to 14 days (Griffith et al., 2005). Guerreiro et al. also demonstrated that when neonatal human dermal fibroblasts were immobilised in alginate gels grafted with an RGD peptide sequence and co-cultured with HUVECs, fibroblasts had the ability to modulate and support the assembly of ECs into capillarylike structures (Guerreiro et al., 2013). In addition, the simultaneous use of bioactive silicate materials together with co-cultures of human dermal fibroblasts and HUVECs resulted in an enhanced formation of highly anastomosed capillary-like structures, with calcium silicate extracts inducing VEGF expression by fibroblasts ( $\mathrm{Li}$ and Chang, 2013). Moreover, normal human lung fibroblasts have been co-cultured with HUVECs in a 3D ECM construct, which allowed the generation of in vitro perfusable microvessel networks, through the use of microfluidic technology (Kim et al., 2013).

The implantation of fibroblasts in co-culture with OECs using 3D tissue constructs has also been described. OECs have been reported to accelerate wound healing for skin applications. PB-derived OECs integrated into human dermal fibroblast layers were capable of actively incorporating into new blood vessels, promoting reoxygenation of the wound bed (Hendrickx et al., 2010).

Chen and colleagues created prevascularised tissue constructs by mixing HUVECs and normal human lung fibroblasts in a fibrinogen solution polymerised through the 
addition of thrombin, in a proof of concept approach (Chen et al., 2009b). Then, human UCB-derived OECs were used and, after being organised into capillary-like networks in vitro, fibrin-based tissue constructs were implanted. Blood perfusion and the formation of anastomosis between vessels from the implanted structure and the host vasculature were observed within $27 \mathrm{~h}$ after implantation, when OECs were co-cultured with a high density of fibroblasts (Chen et al., 2010).

Considering these data together, further studies should be performed using co-cultures of OECs and fibroblasts, in order to understand the molecular mechanisms underlying this cellular crosstalk during the angio-/vasculogenic processes.

\section{Co-cultures of ECs with mesenchymal stem cells}

MSCs can be obtained not only from bone marrow, but also from a variety of other tissues, including blood, adipose tissue, muscle and dermis (Singer and Caplan, 2011). Adult MSCs have gained an increasing interest for regenerative therapies, due to their ability to differentiate into bone, cartilage and fat, together with their immunomodulatory functions (Pittenger et al., 1999; Haniffa et al., 2009; Singer and Caplan, 2011). On the other hand, some MSCs may differentiate into SMCs after implantation, suggesting that these cells may function as perivascular cells ( $\mathrm{Au}$ et al., 2008b). MSCs are multipotent cells and, thus, overcome the problems of using terminally differentiated cells, including the long fabrication time, given their low proliferative capacity and the lack of off-shelf capacity of engineered constructs (He et al., 2010). Au et al. have demonstrated that human BM-derived MSCs were capable of differentiating into functional perivascular cells when co-implanted with HUVECs, stabilising nascent blood vessels, which remained functional for more than 130 days in vivo (Au et al., 2008b). This work also showed that MSCs-derived perivascular cells were able to act in a physiological way, by constricting in response to the addition of endothelin-1, a peptide with endogenous vasoconstrictive function (Au et al., 2008b). Besides, Laranjeira et al. performed co-cultures of human dermal microvascular ECs (HDMEC) with human MSCs and observed that collagen I, which is a pro-angiogenic substrate, and $\mathrm{VEGF}_{165}$ were overexpressed, compared to monocultures of MSCs (Laranjeira et al., 2012). Guerrero et al. showed that there is an increase in the mRNA levels of junctional proteins like $\mathrm{Cx} 43$, when progenitor-derived ECs are co-cultured with MSCs, compared to monocultures (Guerrero et al., 2013).

Starting from the hypothesis that the combination of PB-derived OECs and MSCs could result in a beneficial effect for the generation of pre-vascularised tissue engineered constructs, Kolbe and colleagues performed co-cultures of both cell types in order to study their angiogenic behaviour. In contrast to OECs in monoculture, an increased release of angiogenic factors by MSCs and a considerable formation of angiogenic structures were observed in co-cultures, which obviously depended on the culture media used (Kolbe et al., 2011). These microvessellike structures appeared closely associated with cells that stained positive for SMA (Kolbe et al., 2011). These results highlight the relevance of MSCs as supporting cells for the stabilisation and maturation of newly formed vascular networks, resulting from cellular communication.

Furthermore, the addition of PB-derived EPCs to an in vitro pre-vascularisation model of OECs/MSCs significantly improved the formation of capillary-like structures, with EPCs acting as pro-angiogenic myeloid cells and being co-localised with these structures (Shi et al., 2014). Thus, EPCs might play a role in the in vivo formation of bioengineered vascular networks (MeleroMartin et al., 2010). BM-derived EPCs $\left(\mathrm{CD} 34^{+} / \mathrm{CD}_{133^{+}}\right)$ have been recently reported as forming capillary-like networks when co-cultured with BM-derived MSCs in a $3 \mathrm{D}$ polyurethane scaffold, with luminal tubular structures being observed after 7 days, which did not occur when EPCs were cultured alone (Duttenhoefer et al., 2013). Although EPCs have traditionally been known as participating in angiogenesis through the secretion of paracrine factors, instead of directly incorporating into blood vessels, this work demonstrated the influence of MSCs in the differentiation process towards a mature and functional EC phenotype. Indeed, endothelial markers, including CD31 and vWF were detected in the system (Duttenhoefer et al., 2013), with BM-derived EPCs also influencing the differentiation of MSCs towards a pericytelike phenotype (Loibl et al., 2014).

Finally, ECs have also been described as potentiating the osteogenic response of human foetal MSCs (hfMSCs) in vitro, via paracrine signalling, together with a more robust neovascularisation in co-cultures of OECs/hfMSCs (Liu et al., 2012), showing that co-cultures constitute a bi-directional system.

\section{Co-cultures with osteoblasts}

There is already extensive literature regarding the crosstalk between differentiated ECs and osteoblastic cells, which has been widely investigated to evaluate both the angiogenic and the osteogenic potential for bone tissue regeneration (Fuchs et al., 2007; Fuchs et al., 2009a; Fuchs et al., 2009b; Grellier et al., 2009a; Grellier et al., 2009b; Dohle et al., 2010; Ghanaati et al., 2011). A study concerning cell encapsulation within alginate microspheres showed that mature ECs alone presented almost no metabolic activity after 8 days of in vitro culture but their co-immobilisation with osteoblasts resulted in an enhanced performance in terms of metabolic activity and survival (Grellier et al., 2009b).

ECs were shown to secrete bone morphogenetic protein (BMP)-2 (Kaigler et al., 2005) and BMP-4 (Smadja et al., 2008), which influence MSC differentiation into osteoblasts (Bidarra et al., 2011) that, in turn, release VEGF, enhancing EC viability (Kaigler et al., 2005; Kaigler et al., 2006; Clarkin et al., 2008; Grellier et al., 2009a; Grellier et al., 2009b). In addition, in co-cultures of primary human osteoprogenitors (HOPs) and HUVECs, mRNA levels of TGF- $\beta 1$ and VEGF were upregulated in HOPs, together with an increase of alkaline phosphatase (ALP) activity, stimulated by the co-culture (Guillotin et al., 2008).

Grellier et al. performed co-cultures of HOPs with HUVECs, and reported the formation of a capillary-like 
network after $48 \mathrm{~h}$ in culture, with ECs using osteoblasts as a matrix for spreading (Grellier et al., 2009a). These mature ECs exhibited a similar organisation when cultured in the presence of conditioned medium from co-cultures, suggesting that a direct contact is needed for the production of chemo-attractive factors, since the same organisation was not observed using conditioned medium from osteoblastic cells cultured alone (Grellier et al., 2009a). Moreover, in vivo assays showed that human bone marrow stromal cells and HUVECs immobilised within alginate microspheres promoted a significant mineralisation in a bone defect, compared to the marrow cells alone (Grellier et al., 2009b), which reinforces the need for intrinsic cellular crosstalk in physiological processes, including bone tissue regeneration.

In general, as previously mentioned, OECs are believed to exhibit a promising angiogenic potential that needs to be further explored and understood. In fact, when co-cultured with osteoblasts, PB-derived OECs are capable of forming pre-vascular networks with a vascular lumen both in 2D cultures and in 3D spheroids, which has not been observed for HUVECs (Fuchs et al., 2007). This might be explained by differences in OEC and HUVEC assembly along rigid collagen matrices (Sieminski et al., 2004; Sieminski et al., 2005). On the other hand, Hoffman et al. performed co-cultures of HUVECs with primary osteoblasts in polyurethane scaffolds and verified the formation of multiple tube-like structures, with osteoblasts supporting survival, proliferation and in vitro vasculogenesis by HUVECs (Hofmann et al., 2008).

Moreover, the same authors also performed a similar co-culture system using starch polycaprolactone fibre meshes. They reported the formation of vascular structures closely associated with the scaffold material, observing an in vivo OEC-mediated scaffold vascularisation when OECs were co-implanted with primary osteoblasts, which was not observed for OECs alone (Fuchs et al., 2009a). These co-culture techniques seem to induce an angiogenic activation of OECs, resulting in microvessel-like structures for a pre-vascularisation strategy. Although other studies reported no sign of in vivo formation of a bone-specific matrix (Ghanaati et al., 2011), this beneficial effect of co-cultures could be the result of embedding ECs into a rich ECM produced by the osteoblasts, as well as from an angiogenic activation of ECs through paracrine effects.

In addition, the dynamic development of the same coculture system in silk fibroin constructs was also evaluated and both an increase and a maturation of the in vitro vascular network with culture time was demonstrated through an increase in parameters like tube area, tube length, number of nodes and number of meshes (Fuchs et al., 2009b). Moreover, a time scale has been established, over which human functional vessels are formed when co-cultures of OECs and primary osteoblasts are used. By implanting in vitro-generated co-cultures into immunodeficient mice they observed that, after 2 days, there was evidence of OECspecific vessels and that some human-derived microvessels were already anastomosed with the host vasculature and, simultaneously, several perfused vessels were observed (Ghanaati et al., 2011).
At the molecular level, when these co-cultures were used, an increase in the expression of osteopontin and osteocalcin, markers of osteoblastic differentiation, as well as an upregulation of ALP and collagen I, has been observed (Fuchs et al., 2009b; Grellier et al., 2009a). In addition, mRNA expression of $\mathrm{VEGF}_{165}$ has been detected in monocultures of osteoblasts both in static 2D and dynamic 3D cultures, while the expression of VEGF receptors, Flt-1 and KDR, was significantly upregulated in co-culture systems (Grellier et al., 2009a; Grellier et al., 2009 b). This confirms that osteoblasts produce VEGF ${ }_{165}$, being the protein immediately used by ECs in angiogenic activation processes. Overall, these experiments indicate an ongoing differentiation of the osteoblastic cells in coculture with OECs, as well as ECM deposition (Fuchs et al., 2009a; Fuchs et al., 2009b) and pro-angiogenic factors production by osteoblasts (Dohle et al., 2010). Together, these studies demonstrate that co-cultures or co-implantation of ECs with osteoblastic cells result in a beneficial effect concerning vascularisation processes and osteogenic differentiation.

\section{Co-cultures with other specialised cells}

Through the years, ECs have been used aiming at engineering complex organs. In the field of liver tissue engineering, besides vascularisation, preserving and maintaining hepatocyte phenotype and function constitutes another challenge (Shang et al., 2014). Layer-based coculture models have been developed to mimic key features of liver sinusoids. Here, heterotypic contacts between primary hepatocytes and ECs, either rat liver sinusoidal ECs or modified HUVECs, resulted in the maintenance of hepatocyte-specific functions, having, for instance, beneficial effects on urea and albumin production (Kim and Rajagopalan, 2010; Kang et al., 2013; Shang et al., 2014). In addition, Salerno and colleagues developed an organotypic co-culture system and reported that hepatocytes exhibited well-demarcated cell-cell borders and organised into compact polyhedral cells with round nuclei, mimicking the in vivo phenotype, as a result of interactions with HUVECs, which were able to organise into capillary-like structures (Salerno et al., 2011).

In addition, ECs (rat brain microvascular ECs) have also been used in co-culture with neural cells (like neurons, astrocytes, and microglia) aiming at creating models of the blood-brain and the blood-spinal cord barriers as potential screening tools for pre-clinical drug discovery (Achyuta et al., 2013; Watson et al., 2013).

Moreover, co-culturing ECs with cardiomyocytes is also a commonly used strategy to pre-vascularise engineered cardiac tissues in vitro. For instance, Garzoni et al. developed a 3D model of tissue-like spheroids through a co-culture of cardiomyocytes and HUVECs, reporting the formation of vascular-like structures, which in turn contributed for the maintenance of long-term survival, as well as the contractile ability of the cardiac microtissue (Garzoni et al., 2009). Together, these studies show that each cell type works as an integrated unit inside a complex system constituted by cells, soluble factors and matrix components. 


\section{Overview on Translational Issues and Clinical Concerns}

The translation of vascular tissue engineering products to clinical use implies not only the development of a functional vascular network, but also a rapid anastomosis with the host vasculature. Hence, this topic addresses some of several issues that need to be solved for a successful translation to be achieved (L'Heureux et al., 2007; Duncan and Breuer, 2009).

Cells derived from bone marrow or peripheral blood may constitute a good cell source, as they are readily available from patients by means of bone marrow aspiration or blood collection, respectively, allowing for an autologous strategy. Nonetheless, if cells are used in a heterologous way, donor to donor variation constitutes a problem that needs to be addressed in this field. For instance, graft-versus-host disease has been a major concern in bone marrow transplantation. For some applications, where MSCs can be applied, their immunosuppressive activity might be beneficial for patients. Although MSCs can develop into perivascular cells or even osteoblast-like cells, as seen in previous sections, further studies might be helpful in elucidating immune responses to these coimplantation systems.

On the other hand, cell therapies usually require an in vitro expansion step in order to obtain a sufficient number of cells for transplantation, which results in a substantial manipulation of cell products and, thus, the clinical use of cell-based therapies is subjected to their approval as Advanced Therapy Medicinal Products by certified agencies (George, 2011).

In addition, although the support provided by $3 \mathrm{D}$ artificial matrices is not extensively addressed in this review, the development of biomaterials that can guide the in vivo formation of blood vessels, assuring cell survival and attachment, is a critical step for efficiently engineering and regenerating complex 3D tissues.

Overall, these are major examples of the essential milestones that still need to be considered before the clinical application of the described strategies.

\section{Conclusions and Future Directions}

Cells are the true engineers in tissue regeneration. Cellular strategies constitute a promising way to achieve vascularisation of tissue engineering constructs avoiding the undesirable side effects of delivery of growth factors, cytokines, hormones or other bioactive molecules.

EC transplantation procedures rely on the use of support cells to assure the stabilisation of newly formed vasculature. However, the clinical use of distinct cell types would require different isolation procedures, resulting in an increased morbidity of donor sites. Vascular tissue engineering requires advanced technological strategies to be developed, as different cell types need complex interactions to orchestrate vascularisation processes in very distinct organs in the human body.

In a bench setting, co-culture systems are a useful instrument providing new insights into the molecular mechanisms underlying vascularisation. Future research is needed on the use and optimisation of these coculture systems, which might allow not only to develop implantable vascular tissue engineered constructs, but also to understand the interplay in heterotypic cultures in order to clearly define the cues involved in host cell recruitment to the injury site, in order to improve tissue integration and regeneration.

\section{Acknowledgements}

The authors acknowledge Júlio Borlido-Santos for his help with designing the images.

\section{Disclosure}

The authors report no conflict of interest.

\section{References}

Achyuta A, Conway A, Crouse R, Bannister E, Lee R, Katnik C, Behensky A, Cuevas J, Sundaram S (2013) A modular approach to create a neurovascular unit-on-a-chip. Lab Chip 13: 542-553.

Ankeny RF, Ankeny CJ, Nerem RM, Jo H (2012) Maturing EPCs into endothelial cells: may the force be with EPCs. Am J Physiol Cell Physiol 303:589-591.

Asahara T, Murohara T, Sullivan A, Silver M, Zee Rvd, Li T, Witzenbichler B, Schatteman G, Isner JM (1997) Isolation of putative progenitor endothelial cells for angiogenesis. Science 275: 964-967.

Asahara T, Masuda H, Takahashi T, Kalka C, Pastore C, Silver M, Kearne M, Magner M, Isner JM (1999) Bone marrow origin of endothelial progenitor cells responsible for postnatal vasculogenesis in physiological and pathological neovascularization. Circul Res 85: 221-228.

Assmus B, Schächinger V, Teupe C, Britten M, Lehmann R, Döbert N, Grünwald F, Aicher A, Urbich C, Martin H, Hoelzer D, Dimmeler S, Zeiher AM (2002) Transplantation of progenitor cells and regeneration enhancement in acute myocardial infarction (TOPCAREAMI). Circulation 106: 3009-3017.

Au P, Daheron LM, Duda DG, Cohen KS, Tyrrell JA, Lanning RM, Fukumura D, Scadden DT, Jain RK (2008a) Differential in vivo potential of endothelial progenitor cells from human umbilical cord blood and adult peripheral blood to form functional long-lasting vessels. Blood 111: 1302-1305.

Au P, Tam J, Fukumura D, Jain RK (2008b) Bone marrow-derived mesenchymal stem cells facilitate engineering of long-lasting functional vasculature. Blood 111: 4551-4558.

Badylak SF (2002) The extracellular matrix as a scaffold for tissue reconstruction. Semin Cell Dev Biol 13: $377-383$.

Bergers G, Song S (2005) The role of pericytes in blood-vessel formation and maintenance. Neuro Oncol 7: 452-464. 
Berthod F, Germain L, Tremblay N, Auger FA (2006) Extracellular matrix deposition by fibroblasts is necessary to promote capillary-like tube formation in vitro. J Cell Physiol 207: 491-498.

Berthod F, Symes J, Tremblay N, Medin JA, Auger FA (2012) Spontaneous fibroblast-derived pericyte recruitment in a human tissue-engineered angiogenesis model in vitro. J Cell Physiol 227: 2130-2137.

Bidarra SJ, Barrias CC, Barbosa MA, Soares R, Amédée J, Granja PL (2011) Phenotypic and proliferative modulation of human mesenchymal stem cells via crosstalk with endothelial cells. Stem Cell Res 7: 186-197.

Blocki A, Wang Y, Koch M, Peh P, Beyer S, Law P, Hui J, Raghunath M (2013) Not all MSCs can act as pericytes: functional in vitro assays to distinguish pericytes from other mesenchymal stem cells in angiogenesis. Stem Cells Dev 22: 2347-2355.

Bonanno E, Iurlaro M, Madri JA, Nicosia RF (2000) Type IV collagen modulates angiogenesis and neovessel survival in the rat aorta model. In Vitro Cell Dev Biol Anim 36: 336-340.

Brauer R, Beck IM, Roderfeld M, Roeb E, Sedlacek R (2011) Matrix metalloproteinase-19 inhibits growth of endothelial cells by generating angiostatin-like fragments from plasminogen. BMC Biochem 12: 38 .

Britten MB, Abolmaali ND, Assmus B, Lehmann R, Honold J, Schmitt J, Vogl TJ, Martin H, Schächinger V, Dimmeler S, Zeiher AM (2003) Infarct remodeling after intracoronary progenitor cell treatment in patients with acute myocardial infarction (TOPCARE-AMI): mechanistic insights from serial contrast-enhanced magnetic resonance imaging. Circulation 108: 2212-2218.

Carmeliet P (2005) Angiogenesis in life, disease and medicine. Nature, 438:932-936.

Carmeliet P, Jain RK (2000) Angiogenesis in cancer and other diseases. Nature 407: 249-257.

Carmeliet P, Jain RK (2011) Molecular mechanisms and clinical applications of angiogenesis. Nature 473: 298-307.

Chang HY, Chi J-T, Dudoit S, Bondre C, van de Rijn M, Botstein D, Brown PO (2002) Diversity, topographic differentiation, and positional memory in human fibroblasts. Proc Natl Acad Sci USA 99: 12877-12882.

Chen C-W, Montelatici E, Crisan M, Corselli M, Huard J, Lazzari L, Péault B (2009a) Perivascular multi-lineage progenitor cells in human organs: Regenerative units, cytokine sources or both? Cytokine Growth Factor Rev 20: 429-434.

Chen C-W, Okada M, Proto JD, Gao X, Sekiya N, Beckman SA, Corselli M, Crisan M, Saparov A, Tobita K, Péault B, Huard J (2013) Human pericytes for ischemic heart repair. Stem Cells 31: 305-316.

Chen J-Y, Feng L, Zhang H-L, Li J-C, Yang X-W, Cao X-L, Liu L, Qin H-Y, Liang Y-M, Han H (2012) Differential regulation of bone marrow-derived endothelial progenitor cells and endothelial outgrowth cells by the Notch signaling pathway. PLoS One 7: e43643.

Chen X, Aledia AS, Ghajar CM, Griffith CK, Putnam AJ, Hughes CCW, George SC (2009b) Prevascularization of a fibrin-based tissue construct accelerates the formation of functional anastomosis with host vasculature. Tissue Eng 15: 1363-1371.
Chen X, Aledia AS, Ghajar CM, Griffith CK, Putnam AJ, Hughes CCW, George SC (2010) Rapid anastomosis of endothelial progenitor cell-derived vessels with host vasculature is promoted by a high density of cotransplanted fibroblasts. Tissue Eng 16: 585-594.

Cheng C-C, Chang S-J, Chueh Y-N, Huang T-S, Huang P-H, Cheng S-M, Tsai T-N, Chen J-W, Wang H-W (2013) Distinct angiogenesis roles and surface markers of early and late endothelial progenitor cells revealed by functional group analyses. BMC Genomics 14: 182.

Clarkin CC, Emery RJ, Pitsillides AA, Wheeler-Jones CPD (2008) Evaluation of VEGF-mediated signaling in primary human cells reveals a paracrine action for VEGF in osteoblast-mediated crosstalk to endothelial cells. J Cell Physiol 214: 537-544.

Conway EM, Collen D, Carmeliet P (2001) Molecular mechanisms of blood vessel growth. Cardiovasc Res 49: 507-521.

Corselli M, Chen C-W, Sun B, Yap S, Rubin JP, Péault B (2012) The tunica adventitia of human arteries and veins as a source of mesenchymal stem cells. Stem Cells Dev 21: $1299-1308$.

Costa C, Incio J, Soares R (2007) Angiogenesis and chronic inflammation: cause or consequence? Angiogenesis 10: $149-166$.

Craig LE, Spelman JP, Strandberg JD, Zink MC (1998) Endothelial cells from diverse tissues exhibit differences in growth and morphology. Microvasc Res 55: 65-76.

Crisan M, Yap S, Casteilla L, Chen C-W, Corselli M, Park TS, Andriolo G, Sun B, Zheng B, Zhang L, Norotte C, Teng P-N, Traas J, Schugar R, Deasy BM, Badylak S, Buhring H-J, Giacobino J-P, Lazzari L, Huard J, Péault B (2008) A perivascular origin for mesenchymal stem cells in multiple human organs. Cell Stem Cell 3: 301-313.

Daley WP, Peters SB, Larsen M (2008) Extracellular matrix dynamics in development and regenerative medicine. J Cell Sci 121: 255-264.

Davis GE, Senger DR (2005) Endothelial extracellular matrix: biosynthesis, remodeling, and functions during vascular morphogenesis and neovessel stabilization. Circulation 97: 1093-1107.

Dejana E, Corada M, Lampugnani MG (1995) Endothelial cell-to-cell junctions. FASEB J 9: 910-918.

Demidova-Rice TN, Geevarghese A, Herman IM (2011) Bioactive peptides derived from vascular endothelial cell extracellular matrices promote microvascular morphogenesis and wound healing in vitro. Wound Repair Regen 19: 59-70.

Dohle E, Fuchs S, Kolbe M, Alexander Hofmann, Schmidt H, Kirkpatrick CJ (2010) Sonic hedgehog promotes angiogenesis and osteogenesis in a coculture system consisting of primary osteoblasts and outgrowth endothelial cells. Tissue Eng Part A 16: 1235-1246.

Dohle E, Fuchs S, Kolbe M, Hofmann A, Schmidt H, Kirkpatrick CJ (2011) Comparative study assessing effects of sonic hedgehog and VEGF in a human co-culture model for bone vascularization strategies. Eur Cells Mater 21: 144-156.

Doulatov S, Notta F, Laurenti E, Dick JE (2012) Hematopoiesis: a human perspective. Cell Stem Cell 10: 120-136. 
Duncan DR, Breuer CK (2009) Challenges in translating vascular tissue engineering to the pediatric clinic. Vascular Cell 3: 23.

Duttenhoefer F, Lara de Freitas R, Meury T, Loibl M, Benneker LM, Herrmann M, Richards RG, Alini M, Verrier S (2013) 3D scaffolds co-seeded with human endothelial progenitor and mesenchymal stem cells: evidence of prevascularization within 7 days. Eur Cells Mater 26: 4965.

Fang JS, Dai C, Kurjiaka DT, Burt JM, Hirschi KK (2013) Cx45 regulates endothelial-induced mesenchymal cell differentiation toward a mural cell phenotype. Arterioscler Thromb Vasc Biol 33: 362-368.

Finkenzeller G, Graner S, Kirkpatrick CJ, Fuchs S, Stark GB (2009) Impaired in vivo vasculogenic potential of endothelial progenitor cells in comparison to human umbilical vein endothelial cells in a spheroid-based implantation model. Cell Prolif 42: 498-505.

Foubert P, Matrone G, Souttou B, Leré-Déan C, Barateau Vr, Plouët J, Ricousse-Roussanne SL, Lévy BI, Silvestre J-S, Tobelem G (2008) Coadministration of endothelial and smooth muscle progenitor cells enhances the efficiency of proangiogenic cell-based therapy. Circul Res 103: 751-760.

Fuchs S, Hermanns MI, Kirkpatrick CJ (2006a) Retention of a differentiated endothelial phenotype by outgrowth endothelial cells isolated from human peripheral blood and expanded in long-term cultures. Cell Tissue Res 326: 79-92.

Fuchs S, Motta A, Migliaresi C, Kirkpatrick CJ (2006b) Outgrowth endothelial cells isolated and expanded from human peripheral blood progenitor cells as a potential source of autologous cells for endothelialization of silk fibroin biomaterials. Biomaterials 27: 5399-5408.

Fuchs S, Hofmann A, Kirkpatrick CJ (2007) Microvessel-like structures from outgrowth endothelial cells from human peripheral blood in 2-dimensional and 3-dimensional co-cultures with osteoblastic lineage cells. Tissue Eng 13: 2577-2588.

Fuchs S, Ghanaati S, Orth C, Barbeck M, Kolbe M, Hofmann A, Eblenkamp M, Gomes M, Reis RL, Kirkpatrick CJ (2009a) Contribution of outgrowth endothelial cells from human peripheral blood on in vivo vascularization of bone tissue engineered constructs based on starch polycaprolactone scaffolds. Biomaterials 30: 526-534.

Fuchs S, Jiang X, Schmidt H, Dohle E, Ghanaati S, Orth C, Hofmann A, Motta A, Migliaresi C, Kirkpatrick CJ (2009b) Dynamic processes involved in the prevascularization of silk fibroin constructs for bone regeneration using outgrowth endothelial cells. Biomaterials 30: $1329-1338$.

Fuchs S, Dohle E, Kolbe M, Kirkpatrick CJ (2010) Outgrowth endothelial cells: sources, characteristics and potential applications in tissue engineering and regenerative medicine. Adv Biochem Eng Biotechnol 123: 210-217.

Gaengel K, Genové G, Armulik A, Betsholtz C (2009) Endothelial-mural cell signaling in vascular development and angiogenesis. Arterioscler Thromb Vasc Biol 29: 630638.
Garzoni LR, Rossi MID, de Barros APDN, Guarani V, Keramidas M, Balottin LBL, Adesse D, Takiya CM, Manso PP, Otazú IB, Meirelles MdN, Borojevic R (2009) Dissecting coronary angiogenesis: $3 \mathrm{D}$ co-culture of cardiomyocytes with endothelial or mesenchymal cells. Exp Cell Res 315: 3406-3418.

George AL, Bangalore-Prakash P, Rajoria S, Suriano R, Shanmugam A, Mittelman A, Tiwari RK (2011) Endothelial progenitor cell biology in disease and tissue regeneration. J Hematol Oncol 4: 24.

George B (2011) Regulations and guidelines governing stem cell based products: clinical considerations. Perspect Clin Res 2: 94-99.

Ghanaati S, Fuchs S, Webber MJ, Orth C, Barbeck M, Gomes ME, Reis RL, Kirkpatrick CJ (2011) Rapid vascularization of starch-poly(caprolactone) in vivo by outgrowth endothelial cells in co-culture with primary osteoblasts. J Tissue Eng Regen Med 5: 136-143.

Grellier M, Ferreira-Tojais N, Bourget C, Bareille R, Guillemot F, Amédée J (2009a) Role of vascular endothelial growth factor in the communication between human osteoprogenitors and endothelial cells. J Cell Biochem 106: 390-398.

Grellier M, Granja PL, Fricain J-C, Bidarra SJ, Renard M, Bareille R, Bourget C, Amédée J, Barbosa MA (2009b) The effect of the co-immobilization of human osteoprogenitors and endothelial cells within alginate microspheres on mineralization in a bone defect. Biomaterials 30: 3271-3278.

Griffith CK, Miller C, Sainson RCA, Calvert JW, Jeon NL, Hughes CCW, George SC (2005) Diffusion limits of an in vitro thick prevascularized tissue. Tissue Eng 11: 257-266.

Guerreiro SG, Brochhausen C, Negrão R, Barbosa MA, Unger RE, Kirkpatrick CJ, Soares R, Granja PL (2012) Implanted neonatal human dermal fibroblasts influence the recruitment of endothelial cells in mice. Biomatter 21: 43-52.

Guerreiro SG, Oliveira MJ, Barbosa MA, Soares R, Granja PL (2013a) Neonatal human dermal fibroblasts immobilized in RGD-alginate induce angiogenesis. Cell Transplant in press.

Guerrero J, Catros S, Derkaoui S-M, Lalande C, Siadous R, Bareille R, Thébaud N, Bordenave L, Chassande O, Visage CL, Letourner D, Amédée J (2013b) Cell interactions between human progenitor-derived endothelial cells and human mesenchymal stem cells in three-dimensional macroporous polysaccharide-based scaffold promote osteogenesis. Acta Biomater 9: 82008213.

Guillotin B, Bareille R, Bourget C, Bordenave L, Amédée J (2008) Interaction between human umbilical vein endothelial cells and human osteoprogenitors triggers pleiotropic effect that may support osteoblastic function. Bone 42: 1080-1091.

Haniffa MA, Collin MP, Buckley CD, Dazzi F (2009) Mesenchymal stem cells: the fibroblasts' new clothes? Haematologica 94: 258-263.

Hayashi K, Nakao S, Nakaoke R, Nakagawa S, Kitagawa N, Niwab M (2004) Effects of hypoxia on 
endothelial/pericytic co-culture model of the blood-brain barrier. Regul Pept 123: 77-83.

He W, Nieponice A, Soletti L, Hong Y, Gharaibeh B, Crisan M, Usas A, Peault B, Huard J, Wagner WR, Vorp DA (2010) Pericyte-based human tissue engineered vascular grafts. Biomaterials 31: 8235-8244.

Hendrickx B, Verdonck K, Van den Berge S, Dickens S, Eriksson E, Vranckx JJ, Luttun A (2010) Integration of blood outgrowth endothelial cells in dermal fibroblast sheets promotes full thickness wound healing. Stem Cells 28: 1165-1177.

Hirschi KK, Burt JM, Hirschi KD, Dai C (2003) Gap junction communication mediates transforming growth factor- $\beta$ activation and endothelial-induced mural cell differentiation. Circul Res 93: 429-437.

Hofmann A, Ritz U, Verrier S, Eglin D, Alini M, Fuchs S, Kirkpatrick CJ, Rommens PM (2008) The effect of human osteoblasts on proliferation and neo-vessel formation of human umbilical vein endothelial cells in a long-term 3D co-culture on polyurethane scaffolds. Biomaterials 29: 4217-4226.

Hurley JR, Balaji S, Narmoneva DA (2010) Complex temporal regulation of capillary morphogenesis by fibroblasts. Am J Physiol Cell Physiol 299: 444-453.

Hynes RO (2007) Cell-matrix adhesion in vascular development. J Thromb Haemost 5: 32-40.

Ingram DA, Mead LE, Tanaka H, Meade V, Fenoglio A, Mortell K, Pollok K, Ferkowicz MJ, Gilley D, Yoder MC (2004) Identification of a novel hierarchy of endothelial progenitor cells using human peripheral and umbilical cord blood. Blood 104: 2752-2760.

Itoh Y, Toriumi H, Yamada S, Hoshino H, Suzuki N (2011) Astrocytes and pericytes cooperatively maintain a capillary-like structure composed of endothelial cells on gel matrix. Brain Res 1406: 74-83.

Jain RK (2003) Molecular regulation of vessel maturation. Nature 9: 685-693.

Junker JP, Lonnqvist S, Rakar J, Karlsson LK, Grenegard M, Kratz G (2013) Differentiation of human dermal fibroblasts towards endothelial cells. Differentiation 85: 67-77.

Kaigler D, Krebsbach PH, West ER, Horger K, Huang Y-C, Mooney DJ (2005) Endothelial cell modulation of bone marrow stromal cell osteogenic potential. FASEB J 19: 665-667.

Kaigler D, Wang Z, Horger K, Mooney DJ, Krebsbach PH (2006) VEGF scaffolds enhance angiogenesis and bone regeneration in irradiated osseous defects. J Bone Miner Res 21: 735-744.

Kale S, Hanai J-i, Chan B, Karihaloo A, Grotendorst G, Cantley LG, Sukhatme VP (2005) Microarray analysis of in vitro pericyte differentiation reveals an angiogenic program of gene expression. FASEB J 19: 270-271.

Kalka C, Masuda H, Takahashi T, Kalka-Moll W, Silver M, Kearney M, Li T, Isner J, Asahara T (2000) Transplantation of ex vivo expanded endothelial progenitor cells for therapeutic neovascularization. Proc Natl Acad Sci USA 97: 3422-3427.

Kalluri R, Zeisberg M (2006) Fibroblasts in cancer. Nat Rev Cancer 6: 392-401.
Kang YB, Rawat S, Cirillo J, Bouchard M, Noh HM (2013) Layered long-term co-culture of hepatocytes and endothelial cells on a transwell membrane: toward engineering the liver sinusoid. Biofabrication 5: 85-92.

Kim S, Lee H, Chung M, Jeon NL (2013) Engineering of functional, perfusable 3D microvascular networks on a chip. Lab Chip 13: 1489-1500.

Kim Y, Rajagopalan P (2010) 3D hepatic cultures simultaneously maintain primary hepatocyte and liver sinusoidal endothelial cell phenotypes. PLoS One 5: e15456.

Kolbe M, Xiang Z, Dohle E, Tonak M, Kirkpatrick CJ, Fuchs S (2011) Paracrine effects influenced by cell culture medium and consequences on microvessel-like structures in cocultures of mesenchymal stem cells and outgrowth endothelial cells. Tissue Eng 17: 2199-2212.

Korff T, Kimmina S, Martiny-Baron G, Augustin HG (2001) Blood vessel maturation in a 3-dimensional spheroidal coculture model: direct contact with smooth muscle cells regulates endothelial cell quiescence and abrogates VEGF responsiveness. FASEB J 15: 447-457.

Kunz-Schughart LA, Schroeder JA, Wondrak M, Rey Fv, Lehle K, Hofstaedter F, Wheatley DN (2006) Potential of fibroblasts to regulate the formation of threedimensional vessel-like structures from endothelial cells in vitro. Am J Physiol Cell Physiol 290: 920-926.

Kusuma S, Zhao S, Gerecht S (2012) The extracellular matrix is a novel attribute of endothelial progenitors and of hypoxic mature endothelial cells. FASEB J 26: 4925-4936.

L'Heureux N, Dusserre N, Marini A, Garrido S, Fuente Ldl, McAllister T (2007) Technology Insight: the evolution of tissue-engineered vascular grafts - from research to clinical practice. Nat Clin Pract Cardiovasc Med 4: 389395.

Langer R, Vacanti JP (1993) Tissue engineering. Science 260: 920-926.

Laranjeira MS, Fernandes MH, Monteiro FJ (2012) Reciprocal induction of human dermal microvascular endothelial cells and human mesenchymal stem cells: time-dependent profile in a co-culture system. Cell Prolif 45: 320-344.

LeBleu VS, MacDonald B, Kalluri R (2007) Structure and function of basement membranes. Exp Biol Med 232: 1121-1129.

Lee K, Silva EA, Mooney DJ (2011) Growth factor delivery-based tissue engineering: general approaches and a review of recent developments. J R Soc Interface 8: 153-170.

Li H, Chang J (2013) Bioactive silicate materials stimulate angiogenesis in fibroblast and endothelial cell co-culture system through paracrine effect. Acta Biomater 9: 6981-6991.

Liebner S, Cavallaro U, Dejana E (2006) The multiple languages of endothelial cell-to-cell communication. Arterioscler Thromb Vasc Biol 26: 1431-1438.

Lin F-J, Tsai M-J, Tsai SY (2007) Artery and vein formation: a tug of war between different forces. EMBO Rep 8: 920-924.

Lin K, Matsubara Y, Masuda Y, Togashi K, Ohno T, Tamura T, Toyoshima Y, Sugimachi K, Toyoda M, 
Marc H, Douglas A (2008) Characterization of adipose tissue-derived cells isolated with the Celution system. Cytotherapy 10: 417-426.

Lin Y, Weisdorf DJ, Solovey A, Hebbel RP (2000) Origins of circulating endothelial cells and endothelial outgrowth from blood. J Clin Invest 105: 71-77.

Liu Y, Teoh S-H, Chong MSK, Lee ESM, Mattar CNZ, Randhawa NSK, Zhang Z-Y, Medina RJ, Kamm RD, Fisk NM, Choolani M, Chan JKY (2012) Vasculogenic and osteogenesis-enhancing potential of human umbilical cord blood endothelial colony-forming cells. Stem Cells 30: 1911-1924.

Loibl M, Binder A, Herrmann M, Duttenhoefer F, Richards RG, Nerlich M, Alini M, Verrier S (2014) Direct cell-cell contact between mesenchymal stem cells and endothelial progenitor cells induces a pericyte-like phenotype in vitro. Biomed Res Int 2014: 395781.

Lovett M, Lee K, Edwards A, Kaplan DL (2009) Vascularization strategies for tissue engineering. Tissue Eng 15: 353-370.

Mansbridge JN, Liu K, Pinney RE, Patch R, Ratcliffe A, Naughton GK (1999) Growth factors secreted by fibroblasts: role in healing diabetic foot ulcers. Diabetes Obes Metab 1: 265-279.

Margariti A, Winkler B, Karamariti E, Zampetaki A, Tsai T-n, Baban D, Ragoussis J, Huang Y, Han J-DJ, Zeng L, Hu Y, Xu Q (2012) Direct reprogramming of fibroblasts into endothelial cells capable of angiogenesis and reendothelialization in tissue-engineered vessels. Proc Natl Acad Sci USA 109: 13793-13798.

Masuda H, Asahara T (2003) Post-natal endothelial progenitor cells for neovascularization in tissue regeneration. Cardiovasc Res 58: 390-398.

Medina RJ, O’Neill CL, Sweeney M, Guduric-Fuchs J, Gardiner TA, Simpson DA, Stitt AW (2010a) Molecular analysis of endothelial progenitor cell (EPC) subtypes reveals two distinct cell populations with different identities. BMC Med Genomics 3: 18.

Medina RJ, O’Neill CL, Humphreys MW, Gardiner TA, Stitt AW (2010b) Outgrowth endothelial cells: characterization and their potential for reversing ischemic retinopathy. Invest Ophthalmol Vis Sci 51: 5906-5913.

Melero-Martin JM, Khan ZA, Picard A, Wu X, Paruchuri S, Bischoff J (2007) In vivo vasculogenic potential of human blood-derived endothelial progenitor cells. Blood 109: 4761-4768.

Melero-Martin JM, Obaldia MED, Allen P, Dudley AC, Klagsbrun M, Bischoff J (2010) Host myeloid cells are necessary for creating bioengineered human vascular networks in vivo. Tissue Eng Part A 16: 2457-2466.

Mukai N, Akahori T, Komaki M, Li Q, KanayasuToyoda T, Ishii-Watabe A, Kobayashi A, Yamaguchi T, Abe M, Amagasa T, Morita I (2008) A comparison of the tube forming potentials of early and late endothelial progenitor cells. Exp Cell Res 314: 430-440.

Muller AM, Hermanns MI, Skrzynski C, Nesslinger M, Muller K-M, Kirkpatrick CJ (2002) Expression of the endothelial markers PECAM-1, vWf, and CD34 in vivo and in vitro. Exp Mol Pathol 72: 221-229.

Munarin F, Guerreiro SG, Grellier MA, Tanzi MC, Barbosa MA, Petrini P, Granja PL (2011) Pectin-based injectable biomaterials for bone tissue engineering. Biomacromolecules 12: 568-577.

Newman AC, Nakatsu MN, Chou W, Gershon PD, Hughes CCW (2011) The requirement for fibroblasts in angiogenesis: fibroblast-derived matrix proteins are essential for endothelial cell lumen formation. Mol Biol Cell 22: 3791-3800.

Njauw C-N, Yuan H, Zheng L, Yao M, Martins-Green M (2008) Origin of periendothelial cells in microvessels derived from human microvascular endothelial cells. Int J Biochem Cell Biol 40: 710-720.

Nolan DJ, Ciarrocchi A, Mellick AS, Jaggi JS, Bambino K, Gupta S, Heikamp E, McDevitt MR, Scheinberg DA, Benezra R, Mittal V (2007) Bone marrow-derived endothelial progenitor cells are a major determinant of nascent tumor neovascularization. Genes Dev 21: 15461558.

Novosel EC, Kleinhans C, Kluger PJ (2011) Vascularization is the key challenge in tissue engineering. Adv Drug Del Rev 65: 300-311.

Oshima-Sudo N, Li Q, Hoshino Y, Nakahama K-i, Kubota T, Morita I (2011) Optimized method for culturing outgrowth endothelial progenitor cells. Inflamm Regen 31: 219-227.

Phelps EA, García AJ (2010) Engineering more than a cell: vascularization strategies in tissue engineering. Curr Opin Biotechnol 21: 704-706.

Pittenger MF, Mackay AM, Beck SC, Jaiswal RK, Douglas R, Mosca JD, Moorman MA, Simonetti DW, Craig S, Marshak DR (1999) Multilineage potential of adult human mesenchymal stem cells. Science 283: 143-147.

Rafii S, Lyden D (2003) Therapeutic stem and progenitor cell transplantation for organ vascularization and regeneration. Nat Med 9: 37-42.

Ratlif BB, Goligorsky MS (2013) Delivery of EPC embedded in HA-hydrogels for treatment of acute kidney injury. Biomatter 3: e23284.

Rouwkema J, Rivron NC, van Blitterswijk C (2008) Vascularization in tissue engineering. Trends Biotechnol 26: 434-441.

Salerno S, Campana C, Morelli S, Drioli E, Bartolo LD (2011) Human hepatocytes and endothelial cells in organotypic membrane systems. Biomaterials 32: 88488859.

Schächinger V, Assmus B, Britten MB, Honold Jr, Lehmann R, Teupe C, Abolmaali ND, Vogl TJ, Hofmann W-K, Martin H, Dimmeler S, Zeiher AM (2004) Transplantation of progenitor cells and regeneration enhancement in acute myocardial infarction: final one-year results of the TOPCARE-AMI trial. J Am Coll Cardiol 44: 1690-1699.

Shang Y, Tamai M, Ishii R, Nagaoka N, Yoshida Y, Ogasawara M, Yang J, Tagawa Y-i (2014) Hybrid sponge comprised of galactosylated chitosan and hyaluronic acid mediates the co-culture of hepatocytes and endothelial cells. J Biosci Bioeng 117: 99-106.

Shi Q, Rafii S, Wu MH-D, Wijelath ES, Yu C, Ishida A, Fujita Y, Kothari S, Mohle R, Sauvage LR, Moore MAS, Storb RF, Hammond WP (1998) Evidence for circulating bone marrow-derived endothelial cells. Blood 92: 362-367. 
Shi Y, Kramer G, Schröder 1, Kirkpatrick CJ, Seekamp A, Schmidt H, Fuchs S (2014) Early endothelial progenitor cells as a source of myeloid cells to improve the prevascularization of bone constructs. Eur Cells Mater 27: 64-80

Sieminski AL, Hebbel RP, Gooch KJ (2004) The relative magnitudes of endothelial force generation and matrix stiffness modulate capillary morphogenesis in vitro. Exp Cell Res 297: 574-584.

Sieminski AL, Hebbel RP, Gooch KJ (2005) Improved microvascular network in vitro by human blood outgrowth endothelial cells relative to vessel-derived endothelial cells. Tissue Eng 11: 1332-1345.

Sieveking DP, Buckle A, Celermajer DS, Ng MKC (2008) Strikingly different angiogenic properties of endothelial progenitor cell subpopulations: insights from a novel human angiogenesis assay. J Am Coll Cardiol 51: 660-668.

Silva EA, Kim E-S, Kong HJ, Mooney DJ (2008) Material-based deployment enhances efficacy of endothelial progenitor cells. Proc Natl Acad Sci USA 105: 14347-14352.

Singer NG, Caplan AI (2011) Mesenchymal stem cells: mechanisms of inflammation. Annu Rev Pathol 6: 457-478.

Smadja DM, Bièche I, Silvestre J-Sb, Germain Sp, Cornet A, Laurendeau I, Duong-Van-Huyen J-P, Emmerich J, Vidaud M, Aiach M, Gaussem P (2008) Bone morphogenetic proteins 2 and 4 are selectively expressed by late outgrowth endothelial progenitor cells and promote neoangiogenesis. Atertio Thromb Vasc Biol 28: 2137-2143.

Soares R (2009) Angiogenesis in the metabolic syndrome. In: Oxidative Stress, Inflammation and Angiogenesis in the Metabolic Syndrome (Soares R, Costa C, eds), Springer Sci Business Media, Dordrecht, Netherlands, pp 85-99.

Sottile J (2004) Regulation of angiogenesis by extracellular matrix. Biochim Biophys Acta 1654: 13-22.

Staton CA, Reed MWR, Brown NJ (2009) A critical analysis of current in vitro and in vivo angiogenesis assays. Int J Exp Pathol 90: 195-221.

Susienka MJ, Medici D (2013) Vascular endothelium as a novel source of stem cells for bioengineering. Biomatter 3: e24647.

Szöke K, Beckstrøm KJ, Brinchmann JE (2012) Human adipose tissue as a source of cells with angiogenic potential. Cell Transplant 21: 235-250.

Takahashi K, Yamanaka S (2006) Induction of pluripotent stem cells from mouse embryonic and adult fibroblast cultures by defined factors. Cell 126: 663-676.

Takahashi K, Tanabe K, Ohnuki M, Narita M, Ichisaka T, Tomoda K, Yamanaka S (2007) Induction of pluripotent stem cells from adult human fibroblasts by defined factors. Cell 131: 861-872.

Tarallo S, Beltramo E, Berrone E, Porta M (2012) Human pericyte-endothelial cell interactions in co-culture models mimicking the diabetic retinal microvascular environment. Acta Diabetol 49: S141-S151.

Tura O, Skinner EM, Barclay GR, Samuel K, Gallagher RC, Brittan M, Hadoke PW, Newby DE, Turner ML, Mills
NL (2013) Late outgrowth endothelial cells resemble mature endothelial cells and are not derived from bone marrow. Stem Cells 31: 338-348.

Vestweber D (2008) VE-Cadherin: The major endothelial adhesion molecule controlling cellular junctions and blood vessel formation. Arterioscler Thromb Vasc Biol 28.

Villars F, Guillotin B, Amédée T, Dutoya S, Bordenave L, Bareille R, Amédée J (2002) Effect of HUVEC on human osteoprogenitor cell differentiation needs heterotypic gap junction communication. Am J Physiol Cell Physiol 282: 775-785.

Wang Z, He Y, Yu X, Fu W, Wang W, Huang H (2012) Rapid vascularization of tissue-engineered vascular grafts in vivo by endothelial cells in co-culture with smooth muscle cells. J Mater Sci Mater Med 23: 1109-1117.

Watson PMD, Paterson JC, Thom G, Ginman U, Lundquist S, Webster CI (2013) Modelling the endothelial blood-CNS barriers: a method for the production of robust in vitro models of the rat blood-brain barrier and bloodspinal cord barrier. BMC Neurosci 14: 59.

Wong T, McGrath JA, Navsaria H (2007) The role of fibroblasts in tissue engineering and regeneration. $\mathrm{Br} \mathrm{J}$ Dermatol 156: 1149-1155.

Yamanaka S (2013) The winding road to pluripotency (Nobel Lecture). Angew Chem Int Ed Engl 52: 1390013909.

Yoder MC, Mead LE, Prater D, Krier TR, Mroueh KN, Li F, Krasich R, Temm CJ, Prchal JT, Ingram DA (2007) Redefining endothelial progenitor cells via clonal analysis and hematopoietic stem/progenitor cell principals. Blood 109: 1801-1809.

Zhang P, Baxter J, Vinod K, Tulenko TN, Muzio PJD (2009) Endothelial differentiation of amniotic fluid-derived stem cells: synergism of biochemical and shear force stimuli. Stem Cells Dev 18: 1299-1308.

Zhang SJ, Zhang H, Hou M, Zheng Z, Zhou J, Su W, Wei Y, Hu S (2007) Is it possible to obtain "true endothelial progenitor cells" by in vitro culture of bone marrow mononuclear cells? Stem Cells Dev 16: 683-690.

Zozulya A, Weidenfeller C, Galla H-J (2008) Pericyteendothelial cell interaction increases MMP-9 secretion at the blood-brain barrier in vitro. Brain Res 1189: 1-11.

\section{Discussion with Reviewers}

M. Herrmann: Endothelial progenitor or blood mononuclear cells are very heterogeneous populations but obviously the interaction of these cells with mature endothelial cells is essential for blood vessel formation and repair. Is it better to use pure populations of individual cells types or can we profit from these natural interactions, what is your opinion?

Authors: We consider that the use of mixed endothelial cell populations might be beneficial in terms of their interactions to promote new blood vessels formation. Indeed, as, for instance, EPCs and OECs have been reported to influence angiogenic processes through distinct mechanisms, the use 
of a mixture of these cell types could positively influence vascularisation in vivo, as also described by Silva et al. (2008; text reference). The same can happen when mature ECs are present, as they already have a functional endothelial phenotype. Indeed, the incorporation of OECs into capillary-like structures previously formed by mature ECs has also been reported (e.g., Sieveking et al., 2008; text reference). Thus, these distinct populations seem to act/interact in a synergistic manner. 